\title{
Media Literacy, Curriculum and The Rights of the Child
}

\section{Authors:}

Corresponding Author: Dr Michelle Cannon - Lecturer in Media in Education, UCL Institute of Education, UCL Knowledge Lab, London. Contact: m.cannon@ucl.ac.uk

Dr Steve Connolly - Senior Lecturer in Teacher Education, University of Bedfordshire. Contact: steve.connolly@beds.ac.uk

Dr. Rebecca Parry -Lecturer in Digital literacies, Director MA Digital Literacies, Culture and Education School of Education, University of Sheffield. Contact: R.L.Parry@ sheffield.ac.uk

\section{Word Count: 6737}

\begin{abstract}
Engaging with digital media is part of everyday living for the majority of children, yet opportunities to learn about, through and with media are denied many pupils in compulsory schooling. Whilst Media Studies in the UK is internationally reputed to be well established, changes made to the primary and secondary national curriculum in 2014 included removal of existing media study elements. We demonstrate what is lost by these actions in relation to the United Nations Rights of the Child and, in particular, the right of the child to express identity. We demonstrate how media literacy had previously been included in curriculum, enabling opportunities to address children's rights, and propose that the absence of media education is part of an overall trend of the non-prioritisation of children's rights in England and Northern Ireland. The paper calls for media literacy to be reintroduced into primary and secondary curriculum.
\end{abstract}

Keywords: children's rights, identity, media education, media literacy, popular culture, criticality, creative learning. 


\section{Introduction}

Education plays an important role in enabling countries to prioritise and provide resources to ensure children's rights are upheld. In this paper we demonstrate that a narrowing of curriculum and anachronistic approaches to literacy can be linked to the poor ranking of the UK (169th out of 182 countries) in meeting its UNCRC commitments. In particular the UN adjudicating committee have raised concerns over the inadequate provision of play, leisure, arts and cultural life for children in parts of the UK and Northern Ireland (UNCRC 2016, p.19). Engagements with digital media feature as part of everyday living for children from the earliest years (Marsh, 2019) and play an important role in relation to the way children develop literacies and identities (Potter, 2012). However, opportunities to learn about, through and with media in compulsory schooling in England (in the 4-18 age range) have been reduced due to changes to the English national curriculum in 2014.

Bazalgette et al. (2011) demonstrate that media education creates a context for children to critically engage with media, to access media from a range of cultural contexts, and to create media to explore and express their own experiences and perspectives (sometimes referred to as the Three C's approach - critical, cultural and creative). The absence of media education in the curriculum for England has limited these possibilities, preventing schools from meaningfully addressing the UNCRC in particular with respect to the right of the child to express their identity. Firstly, we describe the ways in which media education has been both present and absent in curriculum in England. We subsequently establish the relationship between the development of media literacy and the UNCRC by mapping Media Studies pedagogies with key Articles that relate particularly to expressions of identity. We then return to resonant (MacLure, 2013) data collected as part of the Developing Media Literacy (DML) project funded by the ESRC in 2010, at a time when secondary schools were able to develop 
a subject specialism in Media Arts and media literacy was still inscribed in the 2007 curriculum. We re-examine the previously overlooked aspects of media literacy pedagogies in the data and suggest links that can be made specifically with UNCRC Articles $8,12,13,17$ and 30. The authors are revisiting DML research vignettes that continue to have resonance but which were not included in key outputs at the time (Burn, A., et al. 2010; Connolly \& Parry 2018; Partington \& Buckingham 2012; Powell, 2014). These vignettes are reframed here in the light of changes in education policy, to explore what has been lost in the intervening years.

\section{Media Education and Curriculum}

Prior to 2014, elements of media literacy had been included in the study of English and in response to changing understandings of literacy (Buckingham 2003; Connolly 2019), promulgated by the need for curriculum and pedagogic reform that reflected changes in society and in response to the schism between the media knowledge, skills and dispositions that many children bring to the classroom (Marsh 2009; Potter \& McDougall 2017; Scott 2016). Although frequently dismissed and even mocked by both government officials and journalists in the UK (Bennett \& Kidd 2017), Media Studies was a well-established subject in secondary education, at a time when such GCSE optional courses were available to them. Crucially, it involved critical engagement with key ideas that underpin notions of democracy and identity, such as questioning who owns and makes editorial decisions in relation to news, or how black and ethnic minorities are represented in online and offline film and media texts.

The traditional conceptual framework of Media Studies, focusing on Texts, Audiences, Institutions and Representations, intersects with pedagogies aiming to develop criticality and creativity (Buckingham, 2003). Although this framework has been the subject of debate, especially in relation to the move to the digital and expansion of the internet (Bennett \& 
Maton 2010), these concepts have retained their value in enabling the framing of questions that develop criticality. In the UK context, debates about the subject, a sign of healthy disciplinary development, were curtailed when reference to media was removed from the English National Curriculum in 2014. This decision was ideologically motivated as part of the 'strangulation' (Buckingham 2017) of the discipline (Buckingham 2014 and 2019; Connolly 2019).

Numerous education policy changes of the past decade were driven by former Secretary of State for Education, Michael Gove's, model of education, which constitutes a neoliberal appropriation of the concepts of social, educational and cultural capital. Gove and his allies positioned themselves as advocates for high art and high culture for all, arguing that study of popular culture is an underestimation of students' capabilities. In doing so, much of the progress and development of media learning in schools was undermined, eroding learners' rights to engage with representations of multiple identities (Potter 2012) through popular media. What is more, such is the focus on school performance in this context that any teachers wishing to use their autonomy and expertise to teach media literacy would find it hard to justify any focus not prescribed in curriculum.

The current iteration of UK curriculum makes a strong division between formal individualistic and assessable schooled literacies, and 'home' literacies which might include informal media-related engagements, such as video-gaming and video-editing, whereas European research studies (Kumpulainen et al. 2018; Marsh 2013) point out the advantages of linking media ecologies at home with literacy learning from the youngest age. Creating these continuities between the two main life worlds of the child ensures that the child's right to enjoy already familiar language and culture is met. In contrast, the curriculum for Literacy and now English in England, has retreated from this research-led orientation to literacy, and 
focuses instead on performativity and centrally prescribed literacy objectives where traditional printed texts are dominant. As a result contemporary literacies, enriched by children's engagements with digital media (Burnett et al., 2017; Burnett \& Merchant 2015; Cannon 2018) are subjugated. Bazalgette (2010) suggests that ignoring new modes of audiovisual inscription and the attendant shift from page to screen means risking the disenfranchisement of both pupil and teacher. This potentially compounds disadvantage for many children where there are discrepancies between practices with digital media tools and platforms in low income households, and those with more economic and social advantage (Sandberg et al. 2018; Scott 2016).

In place of media education, a version of digital literacy has been introduced and positioned within the ICT curriculum. Here the focus is narrow and the emphasis placed on the functional acquisition of skills, this time with a future-focus (Facer, 2019) in relation to developing an economically competitive workforce with digital skills. Outside the literacy curriculum, suggested new iterations of digital skills and competencies needed for the $21 \mathrm{st}$ century tend to focus on operational skills, privacy and security, in isolation from more creative and cultural practices. Media educators and scholars (Burn et al. 2014; Cannon et al. 2018; Cannon \& Potter 2019; Parry 2014) argue for a greater balance to be struck between the epistemological and the ontological, in other words, between current trends favouring the transmission of fixed content and knowledge, and the kinds of exploration of identity and popular culture afforded by creative media practices. In this view, young people's right to deeper understandings of their lived cultural experience is foregrounded rather than preoccupations with competitive economic advantage or with prescribed notions of what constitutes legitimate knowledge. 
In many other international contexts the literacy curriculum has been re-imagined to acknowledge the multiple ways of making meaning beyond canonical written modes. Kumpulainen (2019) outlines the ways in which the Finnish curriculum has adopted 'multiliteracies' (New London Group 1996), a strategy that responds to the impact of changes to literacy in terms of new technologies, and the increasing plurality and cultural diversity of society. Media literacy is well established as a subject in its own right in Finland, but recent reforms ensure that literacy is not thought of as a singular set of skills to be acquired, but as plural and dynamic (Potter \& McDougall 2017). The emphasis on multiliteracies positions media education not only within the core literacy curriculum, but as transdisciplinary, in ways that include learner dispositions and capacities that cut across subject areas.

International early years education has also become a site for innovation in relation to media literacy. Cowan (2019) demonstrates how a Reggio Emilia approach informs creative practices with digital and other craft materials in three Swedish pre-schools, reinforcing the need for play, experimentation and creativity (Beavis et al. 2017). Meanwhile in England, there is a disconnect between the rich legacy of research and professional development in the field, and that which informs current international policy and practice (Bazalgette 1989; Marsh \& Millard 2000; Scolari 2018). This sad trajectory has implications for the appropriate development of children and young people's sense of agency and self, in a world characterized by precarity and volatility. In the next section, we highlight the ways in which developing media literacy in schools enables children to express themselves in different forms and to develop their identities and orientations to the world. We demonstrate how the conceptual framework of media education and associated pedagogies create opportunities to address key articles of the UNCRC that ultimately serve to equip children with the critical, creative and cultural capacity for meaningful social participation and transformation. 


\section{Media Literacy and Children's Rights}

Media education has the potential to enable schools and nations to begin to meet their commitments to the UNCRC, particularly with regard to the following Articles relating to identity, social and cultural participation and multisensorial expression.

\section{Article 8}

The authors propose that being media literate with the ability to manipulate expressive multimodal resources begins to address the articulation and development of identity as alluded to in Article 8:

'the right of the child to preserve his or her identity, including nationality, name and family relations as recognized by law without unlawful interference.'

(UNCRC, 1989. Article 8)

The concept of media literacy emerged from the broader tradition of Cultural Studies which recognises children's popular cultures as worthy of study, and takes a social justice approach in terms of pedagogies. Media education theorists propose that learning of this nature leads to the development of a particular civic and social disposition, amounting to heightened critical understanding (Mihailidis 2018). This thesis revolves around the positive ways in which youth can express understanding of aspects of themselves and their own local environment through media. Media performs an important role in creating opportunities for children to explore and curate their own and others' identities through related play, talk and text-making (Potter 2012). Through critical analysis and creative production of media texts children are able to recognise patterns in the way the media represents the world; they can 'preserve' their identities, but more importantly try on a range of digital fluid identities both as individuals and as members of wider groups. 


\section{Article 12}

Similarly, through critical engagement with and authoring of digital texts, children can find ways of expressing their understanding in multimodal forms which increase opportunities to embody ideas in audiovisual form as well as in written language. This aligns with Article 12 which requires provision to be made for:

the child who is capable of forming his or her own views to express those views freely in all matters affecting the child, the views of the child being given due weight in accordance with the age and maturity of the child.

(UNCRC, 1989. Article 12)

In order to freely express themselves young people need opportunities to develop their own perspectives and understanding of issues that affect them, and to appropriate meaningful ways of articulating these views. Media education creates conditions whereby questions can be posed about issues in the news, current debates and social phenomena, it involves the collective production of media texts, enabling children to identify the forms which best suit them. Furthermore, media education provides a conceptual framework that supports a critical reading of texts in which implicit knowledge can be made explicit. For example, the concept of institution generates questions about who owns, funds, creates and influences the production of media texts (Parry \& Powell 2011). These are political questions that encourage the habit of asking questions that begin to challenge everyday assumptions, and query less visible hegemonic structures. Children make choices about issues that impact on their lives based on what they know and are familiar with, the authors believe that intuitive media knowledge can and should be "given due weight", by being built on and mobilised in the service of critique and freedom of expression. 


\section{Article 13}

Article 13 makes clear the range of media with which all children must be allowed to engage in order to fully participate in society:

The child shall have the right to freedom of expression; this right shall include freedom to seek, receive and impart information and ideas of all kinds, regardless of frontiers, either orally, in writing or in print, in the form of art, or through any other media of the child's choice.

(UNCRC, 1989. Article 13)

Creative production work is integral to media education and enables children to express themselves in different media forms in a context of group work and co-operation, in openended projects sustained over weeks. This involves children taking on different roles and identities, such as editors and producers, looking at the social, cultural and political origins of information sources, and orchestrating multiple modes including sound, moving image and text, to make their own meanings.

Production projects are also mostly collaborative practices that engage with social and dynamic new literacies (Potter \& McDougall 2017), nurturing spaces that promote dialogue between peers and adults about popular motifs and diverse cultural capital (Marsh 2013; Parry 2013; Potter \& Bryer 2016). We have suggested that practical media production supports conceptual development, but it also supports the kind of exploratory arts practices that help to build a confident sense of self: this confidence propagates the desire to be heard (Burn \& Durran 2007; Cannon et al., 2014).

The erosion of media learning and the de-privileging of media arts has led to a decrease in opportunities for production by children in schools. The Durham Commission on Creativity 
and Education (2019) exposes the 'unfair' disparity between schools that embed creative practice and those for whom it is less of a priority. The report recommends that the education system 'should support young people to engage creatively and critically with the digital technology that is now a significant part of their everyday lives (Durham Commission 2019, p.22). We advance that the value of media education to respond to this recommendation and to the mandates within Article 13 is clear and that this affirmation must be made more forcefully in policy circles..

\section{Article 17 and Article 30}

Media education strategies bring to the fore children's right to access a range of cultural texts in order to widen their experiences and ensure they have opportunities to engage with material created in their home countries and in languages other than their own - a strategy that accords with Article 17:

State parties recognize the important function performed by the mass media and shall ensure that the child has access to information and material from a diversity of national and international sources, especially those aimed at the promotion of his or her social, spiritual and moral well-being and physical and mental health.

(UNCRC, 1989. Article 17)

Media education plays a key role in identifying a wide range of texts for young people to engage with which meet the sorts of social, spiritual, and cultural needs recognised in Article 17 above and 30 below, which recommends that:

In those States in which ethnic, religious or linguistic minorities or persons of indigenous origin exist, a child belonging to such a minority or who is indigenous shall not be denied the right, in community with other members of his or her group, to 
enjoy his or her own culture, to profess and practise his or her own religion, or to use his or her own language.

(UNCRC, 1989. Article 30)

Just as it is part of the teacher's job to introduce new works of print fiction to children, teachers have been key to introducing children to the moving image in particular, which might especially resonate with the child. Film education (Cannon 2018; Parry 2013) emphasises the need to understand a range of media languages and offers children from minority backgrounds a means of engaging with their own language through the consumption and production of film.

\section{The Developing Media Literacy (DML) project}

We share two data vignettes drawn from the substantially wider programme of research from the DML project, focussing on a model for learning progression. We reflect on the pedagogies associated with media education and the creation of spaces in which children's experiences of media are valued, voiced and heard. This project, running from January 2009 to January 2012, was the first large-scale, systematic exploration of the practice of media education in schools. The project took place in two contrasting city locations, and focused on year eight and ten in a secondary school and year two and four in two primary schools. The action research involved six classes of approximately 30 children in each site (360 in total) and the classes were followed when they progressed to the subsequent year. One of the methodological approaches included action research, whereby practical schemes of activity were collaboratively planned by teachers and researchers and then implemented in each classroom. The specific aim was to specify what children of different ages and experiences might be expected to understand about media, and how their learning could develop over time. One outcome was a sequence of learning activities published in a document for primary 
teachers by The English and Media Centre. Key findings from this project related to: establishing similarities between teachers and children's home engagements with media (Burn et al., 2010); the importance of the conceptual framework for Media Studies to progression (Parry \& Powell, 2011; Partington \& Buckingham, 2010; Powell, 2014); and its importance to both pedagogy and progression (Parry, 2014).

The vignettes included here come from one of two locations which consisted of a secondary comprehensive school of 800 pupils with, at the time, a Media Arts specialism and its feeder primary schools located in an area of outer London with higher than average levels of pupil deprivation and Special Educational Need. Adult literacy, internet access and family income were all at lower than the median national average level at the time of the project. There were six units of work focused on the media studies conceptual framework, exploring the concepts of narrative, representation, audiences and institutions, taught to four separate age groups; 6-7 year olds, 8-9 year olds, 13-14 year olds and 15-16 year olds. We use Vignette 1 to demonstrate the ways in which Article 8 (around identity), 12 (valuing the views of the child), 13 (freedom of expression) and 17 (exposure to a range of texts) are addressed. Vignette 2 relates to Articles 8, 12, 13, 17 and 30 (the right to enjoy one's own culture).

\section{Vignette 1}

In one Year 11 group of 30 students (15-16 years old) considered some provocative statements such as 'Social media isolates young people'. They were asked to debate, not whether they agreed or disagreed with the statements, but how they would find evidence to support or counter the claims being made, and how they might find evidence to support or challenge each one. The Year 11 group wanted to 'shift the goal posts' to agree or disagree, and firmly resisted the idea of debating. They were keen to share personal experiences and had lengthy discussions about Facebook, examining issues such as generational differences, 
privacy and safety. In relation to the moral panics associated with Facebook, they seemed to reach a consensus that negative public perceptions of social media were ill-informed. However, when their focus turned to the TV show Rastamouse, they were quick to adopt a stance that replicated traditional discourse - one that regarded the show as controversial. Rastamouse was a stop motion animated TV show aimed at the under 6's, featuring a group of skateboarding Jamaican musician/sleuth mice with West Indian accents. None of the students had seen the programme but some had knowledge of associated social media debates. The Year 11s cast children's and parents' relationship with this show as problematic, a set of circumstances that opened up an interesting pedagogic space that the teacher enthusiastically responded to by inviting the students to research the issue further.

Despite considerable vocal engagement by many of the students only one, Flora, undertook and shared some independent research. Flora presented evidence to back up her concerns about the nature of Rastamouse based on one mother's message board comments. The mother complained that if her own white child used the Jamaican slang and dialect from the programme, they would be called racist.

Flora: This is what a mother said "The thing I am not sure about is my daughter saying words like 'Rastaclat' and going up to a child and saying these things. My child is white and if she went up to another child who is not white and said these things it could be an insult" So technically Rastamouse saying things like 'Rastaclat' is not good for children to watch.

Flora proposed that 'technically' this proved her point that television was 'bad for kids' based on the internal logic of the mother's argument. There were some complex positions being 
adopted here: Flora was black in a largely white school, and she perceived the programme to be stereotyping black youth. There was also something uncomfortable about a young black woman adopting the white, potentially racist, mother's position and at this point other members of the group did not feel able to contribute to the discussion. The issue had become complicated and perhaps the students realised that they did not have enough knowledge to take the discussion further.

Open-ended debate seemed to be unfamiliar to this Year 11 group, and adopting the position of a researcher, rather than sharing their own views, was resisted: attempts at critically distanced discourse eluded them. We argue that by giving students some latitude with a controversial issue, the teacher opened a space which at least introduced them to the need for further research in order to challenge initial assumptions and, albeit briefly, to adopt a stance outside their own experience.

In retrospect this moment resonated with the authors for two main reasons. Firstly, the pressure of covering the range of material in GCSE exam specifications meant that any prolonged discussion of a topic initiated by students themselves was unusual. Secondly, this teacher would not have described herself as an expert media educator, but rather an English specialist; indeed, the pervasive nature of media texts makes it difficult for teachers to occupy the space of an expert didact on issues of popular media. We propose that media education productively disrupts classroom hierarchies by valuing learner input and experience as regards media cultures (Cannon et al. 2014; Parry, 2013).

This example of a moment of rapid and engaged discussion was not included in the dissemination of the project but on reflection it resonates as a moment in which the rich potential of pedagogies of 'inexpertise' create learning environments which are participatory 
and 'porous' to the transmedia landscapes that lie beyond school walls (McDougall \& Potter 2015). Within this space a contentious and difficult issue could be tackled and Articles 8,12 and 13 of the UNCRC were addressed. Flora was able to exercise a meaningful right to free speech where she identified a topic of importance of direct relevance to her identity. She took the opportunity to do the research and throw open the debate related to how black lives were being represented and responded to, in an unfamiliar text. The relevance of this exchange to current issues of Black Lives Matter identity politics at the time of writing cannot be lost on the reader (Buckingham 2020; Kelly 2018).

\section{Vignette 2}

The second vignette comes from the same unit dealing with Audiences completed by a different age group at the same school. One group of 30 Year 9 (13-14 year olds) students were asked to plan new TV shows appealing to specific target audiences. - 'Older' People, Teenage Boys, Teenage Girls, ‘20/30 somethings' and Teenage Boys and Girls. Three groups in particular presented complex, challenging and engaging representations reflecting the students and their concerns. They were subsequently asked to pitch their ideas in terms of plot, character, scheduling and audience appeal, to an audience of peers, teachers and researchers who then asked questions.

Group A - four boys - pitched an animated series appealing to teenage boys along the lines of The Simpsons - a text they cited as being influential. One of the members of the group (Paul) had created drawings of characters from the series and included them in the group's presentation. One of the teachers asked him about that digital process:

Teacher: Paul, I noticed you had your characters (on the board) that you created. How did you...it looks like you've done something to them. How did you do that? 
Paul: How do you mean, done something to them?

Teacher: Well, how did you get them on to the screen?

Paul: I drew the outline on paper, then I went to Mr A. 's graphics room and I used the scanner to get the picture on to the computer. Then I figured it out in Photoshop how to put the colours in.

Paul and his peers had not been asked to do this kind of production work, but they had gone to another teacher's classroom in their own time and used industry standard software to prepare character representations to improve the quality of their pitch. Paul clearly enjoyed engaging with the familiar culture of animation and drawing, but this example also suggests that productive experimentation with digital tools had also become routine everyday media practices. The authors have suggested elsewhere (Connolly, 2008; p.36) that this "culture of popular production" is an essential aspect of identity formation in young media learners, connected to the kind of cultural capital generated when young people use technology to create popular media texts. Creative improvisation and self-determination were mobilised by a media production task that motivated the students to move their collaborative learning outside the classroom and into a range of other domains. This vignette demonstrates that the crafting and the playful re-appropriation of familiar media forms within a 'culture of popular texts' (Connolly, 2008; p.34), can mediate important continuities with past as well as present concerns, all the while leveraging pleasure, agency and engagement in learning processes.

Group B, another all-boy group, pitched a TV programme to a broad teenage audience, and created a complex but realistic narrative expressing a desire to have authentic social aspects of their lives heard by other people. In this fictional TV narrative, a pair of siblings had been coerced into care through the manipulation of an abusive social worker named Keith. The marriage of the siblings' parents was breaking up and Keith sought to exploit the situation by 
encouraging the separation of the children from their parents for the express purpose of facilitating his abuse. The siblings hatched a plan to escape, return home and reunite their parents. This plan was dependent on the social worker granting the children the privilege of time on their own, without adult supervision, in return for their submission to his abuse.

When questioned by the adults in the room about the bleak nature of this story, one of the boys, Kieran, mounted a reasoned defence:

The reason why we had Keith is that usually, a social worker would have to be with you, but the children don't want anyone else to find out that they are trying to get their parents back together, so we had to have someone who sees both parts of the story .... Keith wants something from them, and they want something from him, so there's a two way conversation going on.

Kieran is suggesting that the audience had to see how both Keith and the two children were benefiting from this apparently unequal relationship - they needed to be left unsupervised in order to effect their plan, and thus had to give in to Keith's demands. This combination of an exploration of serious issues, via a complex, thought-provoking narrative structure illustrated a stark reality for the adults in the room. These students knew people in care, had met social workers and encountered the difficulties associated with both these groups of people. But there was also a clear sense that the story needed to be presented in a structured way, so that the audience would recognise and relate to the characters.

The structuring of the story suggests an understanding of dramatic irony and the need to build tension, and one might expect at this point in an English lesson for connections to be made between authorial considerations of audience responses, and examples from canonical literature. However, the act of making such analogies is part of the problem. We question why educators should have to justify this kind of creative production in these terms and judge 
any invocation of the canon here as misplaced. The cognitive and creative effort to produce this work has a similar cultural heft to that produced by a student who is asked to write a script based on Macbeth. Indeed, for those who wish to seek support from cognitive science, recent work by Cohn (2019) suggests that we should not see any differences in the kinds of cognitive effort that popular and 'worthy' texts require from our brain; in effect, reading is reading, and complex texts require complex cognition.

With the abandonment of practical media work, and even the removal of the requirement to write creatively from large sections of the English curriculum, the opportunities for young people to undertake creative activity are vanishingly few. The TV show pitches not only presented a genuine creative and cognitive challenge, but also a nuanced exercising of the rights outlined earlier, perhaps the most salient of which is that relating to the need for young people to engage in creative work that arises from their own cultures (Article 30). As mentioned, Cultural Studies framed popular culture as an ongoing dynamic cycle, operating in all sectors of society (Cannon 2018). To deny young people the right to represent their own diverse experiences in the digital forms in which they are habitually immersed, is disempowering and inequitable in terms of curriculum design and content.

\section{Media Education and Children's Rights}

We have demonstrated the ways in which well-established approaches to media education address children's rights, providing examples of pedagogy that support this process. New calls for the rights of the child to be updated for the digital age (Council of Europe 2018; Livingstone 2019) highlight the need for policy and practice to move quickly to regain lost ground in relation to media education, in ways that equip schools and the Inspectorate to respond to changing digital landscapes. Connolly \& Parry (2018) suggest that media 
educators 'carry on' providing children and young people with opportunities to develop media literacies, regardless of the limitations of curriculum and policy, but without a central mandate the geographic spread of these practices will remain uneven and contingent on local skills, resources and priorities. Young people have the right to represent their life-worlds using the digital resources with which they are already familiar, leaving traces of self in critical, creative and informed ways that can be interpreted anew. The authors urge that opportunities for multiple forms of textual analysis and plural modes of expression be reinstated for the re-enfranchisement of children and young people throughout their school years.

\section{References}

Ball, S. J., 2013. Education, Justice and Democracy: The struggle over ignorance and opportunity. London: CLASS: Centre for Labour and Social Studies.

Bazalgette, C., 1989. Primary Media Education: a Curriculum Statement, London: British Film Institute.

Bazalgette, C., 2010. Teaching Media in Primary Schools, London: Sage.

Bazalgette, C., Parry, B. \& Potter, J., 2011. Creative, Cultural and Critical: Media Literacy Theory in the Primary Classroom. In Creative Engagements: Thinking with Children. Oxford, UK: Inter-Disciplinary.net.

Beavis, C., Dezuanni, M. \& O’Mara, J., 2017. Serious play: literacy, learning, and digital games, New York: Routledge. 
Bennett, S. \& Maton, K., 2010. Beyond the 'digital natives' debate: Towards a more nuanced understanding of students' technology experiences. Journal of Computer Assisted Learning, 26(5), pp. 321-331.

Bennett, L. and Kidd, J. (2017) 'Myths about media studies: the construction of media studies education in the British press', Continuum, 31(2), pp. 163-176.

Buckingham, D., 2003. Media Education: Literacy, Learning and Contemporary Culture, Cambridge, UK: Polity.

Buckingham, D., 2014. The Success and Failure of Media Education. Media Education Research Journal, 4(2), pp. 5-17.

Buckingham, D. (2017) The strangulation of Media Studies [online]. Available at: https://davidbuckingham.net/2017/07/16/the-strangulation-of-media-studies/ (Accessed 12 August 2020)

Buckingham, D., 2019. Rewriting education: the legacy of Michael Gove [online]. Available at: https://davidbuckingham.net/2019/08/14/rewriting-education-the-legacy-of-michael-gove (Accessed 12 August 2020)

Buckingham, D., 2020. Decolonising the curriculum ... again? [online]. Available at: https://davidbuckingham.net/2019/08/14/rewriting-education-the-legacy-of-michael-gove (Accessed 12 August 2020)

Burn, A., Buckingham, D., Parry, B., \& Powell, M. (2010). Minding the gaps: teachers' cultures, students' cultures. In (ed) Alvermann, D. Adolescents' Online Literacies: Connecting Classrooms, Digital Media \& Popular Culture. New York. Peter Lang pp. 183202. 
Burn, A. \& Durran, J., 2007. Media Literacy in Schools: Practice, Production and

Progression, London: Paul Chapman.

Burn, A., Potter, J. \& Reid, M., 2014. Media Arts, Digital Culture and Education - Guest Editorial. Media Education Research Journal, 5(1), pp. 5-14.

Burnett, C. \& Merchant, G., 2015. The Challenge of 21st-Century Literacies. Journal of Adolescent \& Adult Literacy, 59(3), pp. 271-274.

Burnett, C., Merchant, G. \& Parry, B., 2017. Past, Present, Future. In Literacy, Media, Technology: Past, Present and Future. London: Bloomsbury, pp. 233-243.

Cannon, M., 2018. Digital Media in Education: Teaching, Learning and Literacy Practices with Young Learners, London: Palgrave Macmillan.

Cannon, M., Bryer, T. \& Lindsey, M., 2014. Media Production and Disruptive Innovation: exploring the interrelations between children, tablets, teachers and texts in subject English settings. Media Education Research Journal, 5(1), pp.16-31.

Cannon, M., Potter, J. \& Burn, A., 2018. Dynamic, Playful and Productive Literacies.

Changing English: Studies in Culture and Education, 25(2), pp.183-199.

Cannon, M. \& Potter, J., 2019. 'Pedagogies of Production: Re-imagining Literacies for the Digital Age', in Hermansson, C. \& Zepernick, J. (eds) The Palgrave Handbook of Children's Film and Television. New York: Palgrave Macmillan, pp. 161-189.

Cohn, N., 2019. 'Your Brain on Comics: A Cognitive Model of Visual Narrative Comprehension', Topics in Cognitive Science (1), pp. 352.

Connolly, S., 2009. “Artistic Reasons/Practical Reasons” Journal of Media Education. 44 
pp. 34-37.

Connolly, S., 2019. 'Whither Media in English', in Goodwyn, A. et al. (eds) The future of English teaching worldwide: celebrating 50 years from the Dartmouth Conference. Abingdon: Routledge.

Connolly, S. \& Parry, B., 2018. 'Media Literacy Education in Primary Years: Carrying on Regardless', Journal of Media Literacy, 65, (1 \& 2).

Council of Europe, Recommendations of the Council of Ministers. 2018. Guidelines to respect, protect and fulfil the rights of the child in the digital environment. Strasbourg: Council of Europe.

Cowan, K., 2019. Digital Meaning Making: Reggio Emilia-inspired Practice in Swedish Preschools. Media Education Research Journal, 8(2), pp. 11-29.

Durham Commission on Creativity and Education. 2019. Durham: Durham University.

Facer, K., 2019. Storytelling in troubled times: what is the role for educators in the deep crises of the 21 st century? Literacy, 53(1), pp. 3-13.

Kelly, L., 2018. A snapchat story: how black girls develop strategies for critical resistance in school. Learning, Media and Technology, 43(4), pp. 374-389.

Kumpulainen, K., Mikkola, A. \& Rajala, A., 2018. Dissolving the Digital Divide: Creating Coherence in Young People's Social Ecologies of Learning and Identity Building. In J. Voogt \& O. Erstad, eds. Curricular Challenges of the 21st Century. Second International Handbook of Information Technology in Primary and Secondary Education. Amsterdam: Springer, Cham, pp. 1-15. 
Kumpulainen, K., 2019. Promoting the Joy of Learning Multiliteracies from Early Years Onwards: An Educational Reform Initiative in Finland. Media Education Research Journal, 8(2), pp. 83-94.

Livingstone, S., 2019. Rethinking the rights of children for the internet age|LSE Media Policy Project, LSE Media Policy Project Blog. [online]. Available at:

https://blogs.lse.ac.uk/medialse/2019/03/18/rethinking-the-rights-of-children-for-the-internetage/ (Accessed 16 September 2020)

MacLure, M., 2013. 'The Wonder of Data', Cultural Studies $\leftrightarrow$ Critical Methodologies. 13(4), pp. 228-232.

Marsh, J., 2009. Productive Pedagogies: Play, Creativity and Digital Cultures in the Classroom. In R. Willett, M. Robinson, \& J. Marsh, eds. Play, Creativity and Digital Cultures. New York: Routledge, pp. 200-218.

Marsh, J., 2013. Early Literacy and Popular Culture. In J. Larson \& J. Marsh, eds. The Sage Handbook of Early Childhood Literacy. Sage, pp. 207-222.

Marsh, J., 2019. 'Researching the digital literacy and multimodal practices of young children', in The Routledge Handbook of Digital Literacies in Early Childhood. Abingdon: Routledge, pp. 19-30.

McDougall, J. \& Potter, J., 2015. Curating Media Learning: Towards a Porous Expertise. Journal of E-learning and Digital Media, 12(2), pp.199-211.

Mihailidis, P., 2018. Civic media literacies: re-Imagining engagement for civic intentionality. Learning, Media and Technology, 43(2), pp.152-164. 
New London Group, 1996. A Pedagogy of Multiliteracies: Designing Social Futures. Harvard Educational Review, 66(1), pp.60-92.

Parry, B. \& Powell, M. (2011) Beyond caricature: recuperating Institution as a productive concept in teaching and learning about media in primary schools, Media Education Research Journal (MERJ) vol 2, pp. 65-73.

Parry, B., 2013. Children, Film and Literacy, Basingstoke: Palgrave Macmillan.

Parry, B., 2014. Popular culture, participation and progression in the literacy classroom. Literacy, 48(1), pp.14-22.

Partington, A., \& Buckingham, D. (2012). Challenging theories: Conceptual learning in the media studies classroom. International Journal of Learning and Media, 3(4), pp. 7-22.

Potter, J., 2012. Digital Media and Learner Identity: the new curatorship, New York: Palgrave Macmillan.

Potter, J. \& Bryer, T., 2016. "Finger flowment” and Moving Image Language: Learning Filmmaking with Tablet Devices. In B. Parry, C. Burnett, \& G. Merchant, eds. Literacy, Media, Technology: Past, Present and Future. London: Bloomsbury, pp.111-128.

Potter, J. \& McDougall, J., 2017. Digital Media, Culture and Education: Theorising Third Space Literacies, London: Palgrave Macmillan.

Powell, M. 2014. 'Media concepts and cultures: progressing learning from and for everyday life.', in Popular culture, pedagogy and teacher education: international perspectives. Abingdon: Routledge, pp. 55-68. 
Sandberg, H., Gillen, J., Aliagas, C., Bar-lev, Y., Jorge, A., Kumpulainen, K., Marsh, J., Matsumoto, M., Morgade, M., Pachedo, R., Tomé, V., 2018. A Day in the Digital Lives of Children aged 0-3: DigiLitEY ISCH COST Action IS1410 Working Group 1 "Digital literacy in homes and communities".

Scolari, C. A., 2018. Teens, Media and Collaborative Cultures. Exploiting Teens' Transmedia Skills in the Classroom. Transliteracy: H2020 Research and Innovations Actions. Barcelona.

Scott, F, L., 2016. Young children's digital literacy practices at home: Social, physical and classed. In I. S. P. Pereira, A. Ramos, \& J. Marsh, eds. The digital literacy and multimodal practices of young children: Engaging with emergent research. COST Action IS1410, University of Minho, Braga, Portugal, 6-8 June, 2016.

UNCRC, 1989. United Nations Convention on the Rights of the Child. Geneva: OHCHR (Office of the High Commissioner for Human Rights).

UNCRC 2016. Committee on the Rights of the Child: Concluding observations on the fifth periodic report of the United Kingdom of Great Britain and Northern Ireland. London. 